\title{
A Rare Cause of Hip Pain in Familial Mediterranean Fever with Patient: Avascular Necrosis
}

\author{
Ailevi Akdeniz Ateşli Hastada Nadir Kalça Ağrısı Nedeni: Avasküler Nekroz
}

Fatih Bağcıer, Ayhan Kul, Akın Erdal

Atatürk University Faculty of Medicine, Department of Physical Medicine and Rehabilitation, Erzurum, Turkey

\section{To the Editor;}

A 22-year-old young man was examined for his complaint of left hip pain for the last one year. He had Familial Mediterranean Fever (FMF) disease for 10 years and was using colchicine $3 \times 1$ a day posology. There was no history of trauma. Hip pain was spreading to the trochanteric region of the hip. The characteristic of the pain was mechanical but he also felt pain while sleeping. Previously, he had received analgesic medications but there had been no significant improvement. There was no abdominal and chest pain and there was no history of disease or trauma associated with the hip. There was no history of FMF attacks for two years. The patient's vital signs were normal. The physical examination was consistent with the painful and limited motions of the left hip joint (flexion: 40 degrees, extension: 30 degrees) with normal neurological findings. Laboratory analysis disclosed increased levels of fibrinogen: 600 (180350) $\mathrm{mg} / \mathrm{dL}$, C-reactive protein: $30 \mathrm{mg} / \mathrm{dL}$, and erythrocyte sedimentation rate: $35 \mathrm{~mm} / \mathrm{s}$. The X-ray images of the left hip joint were suggestive of avascular necrosis of the femoral head (Figure 1). Magnetic resonance imaging findings were consistent with avascular necrosis of the left femoral head (Figure 2). Hyperbaric oxygen therapy (30 sessions) and intravenous non-steroidal anti-inflammatory drug (diclofenac sodium $75 \mathrm{mg} / 3 \mathrm{~mL}$ 2x1 posology along two weeks) was administered. Patient's complaints had not resolved and total hip arthroplasty was performed.

FMF is a hereditary disease characterized by recurrent attacks of fever and serositis. In the clinical course of the disease, also locomotor system symptoms frequently occured. The hip joint is the most vulnerable and likely to be affected by the protracted attacks, which may result in destruction of the articular cartilage and, in some cases, aseptic necrosis of the femoral head. Although there is not enough information about concomitance of FMF and avascular necrosis, rarely avasculer necrosis of the femoral head may be seen (1). We imply that in our clinic practice that FMF should also be included in the roster of differential diagnosis for avascular necrosis of the femoral head (2).

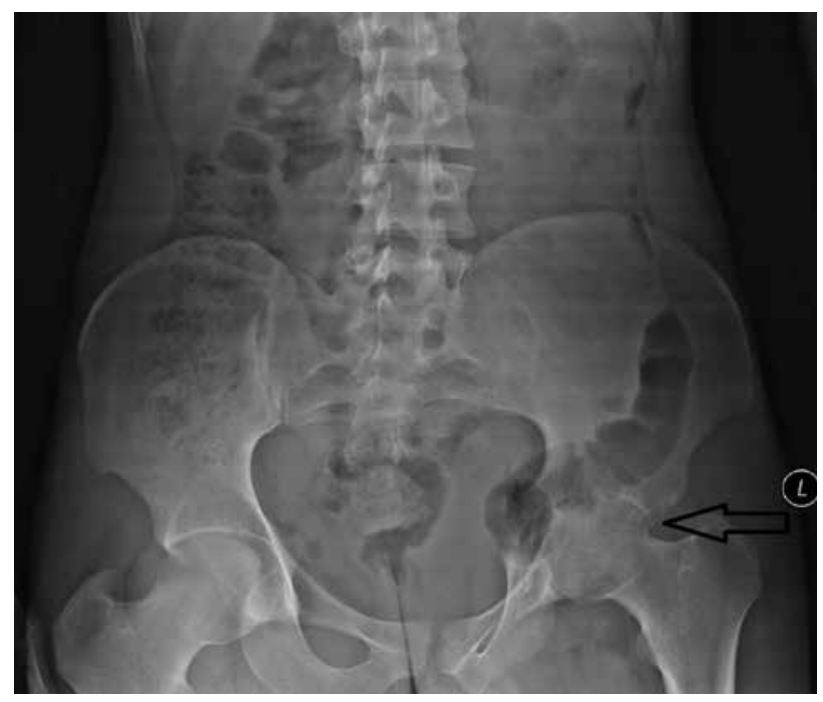

Figure 1. Avascular necrosis of the femoral head

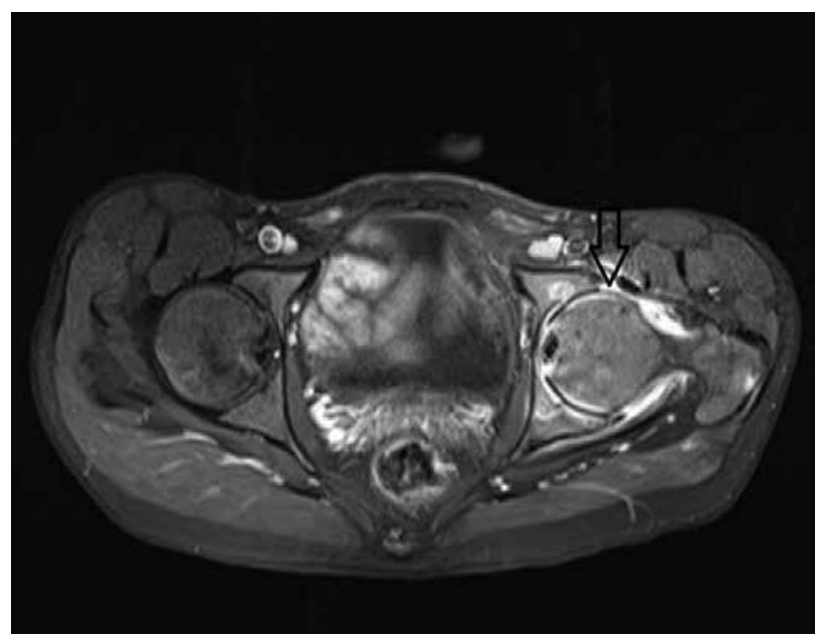

Figure 2. Avascular necrosis of the left femoral head

Address for Correspondence/ Yazışma Adresi: Fatih Bağcıer MD, Atatürk University Faculty of Medicine, Department of Physical Medicine and Rehabilitation, Erzurum, Turkey Phone: +90 5056605754 E-mail: bagcier_42@hotmail.com Received/Geliş Tarihi: 29.08.2015 Accepted/Kabul Tarihi: 10.09.2015

Turkish Journal of Osteoporosis, published by Galenos Publishing. / Türk Osteoporoz Dergisi, Galenos Yayınevi tarafindan basılmıştır. 
Keywords: Familial Mediterranean fever, avasculer nekrosis femoral head

Anahtar kelimeler: Ailevi Akdeniz ateşi, avasküler nekroz, femur başı

\section{Ethics}

Peer-review: Internal peer-reviewed.

\section{Authorship Contributions}

Surgical and Medical Practices: Fatih Bağcıer, Concept: Fatih Bağcıer, Design: Fatih Bağcıer, Data Collection or Processing: Fatih Bağcıer, Analysis or Interpretation: Ayhan Kul, Akın Erdal,
Literature Search: Ayhan Kul, Akın Erdal, Writing: Fatih Bağcıer, Ayhan Kul, Akın Erdal.

Conflict of Interest: No conflict of interest was declared by the authors.

Financial Disclosure: The authors declared that this study received no financial support.

\section{References}

1. Younes $\mathrm{M}, \mathrm{Kahn} \mathrm{MF}$, Meyer O Hip involvement in patients with familial Mediterranean fever. A review of ten cases. Joint Bone Spine 2002:69:560-5

2. Salai M, Langevitz $P$, Blankstein $A$, Zemmer $D$, Chechick $A$, Pras $M$, et al. Total hip replacement in familial Mediterranean fever. Bull Hosp Jt Dis 1993:53:25-28. 